Vom Material der Universitätskinderklinik Sassari ausgehend, habe ich 100 Familien anamnestisch auf Fabismus untersucht und dabei folgende Tatsachen festgestellt:

1. Das starke Überwiegen des männlichen Geschlechtes, das man am klinischen Material antrifft, ist nur an die grössere Schwere der Erkrankung bei den Knaben gebunden.

2. Die grösste Zahl der Fälle manifestiert sich binnen der ersten fünf Lebensjahre.

3. Bei $77 \%$ der Fälle sind beide Eltern normal, bei $21 \%$ eines und bei $2 \%$ beide gegen die Bohnen überempfindlich.

4. Die gefundenen Frequenzen der befallenen Kinder stimmen gut mit den nach BERNSTEIN berechneten überein, und zwar sind von den Kindern gesunder Eltern $1 / 4$, von denen eines kranken $1 / 2$ und von denen beider kranken Eltern alle befallen.

Daraus möchte ich schliessen, dass der Fabismus als ein rezessives Erbleiden anzusehen ist, mit hoher Penetranz und beim männlichen Geschlecht stärkerer Expressivität. Der gefundene Erbgang entspricht nicht dem für die Allergie von anderer Seite vorgeschlagenen.

\section{E. SARTORI}

Kinderklinih der Universität Sassari (Italien), 10. August 1957 .

\section{Summary}

Analysis of 100 families with at last one affected offspring seems conclusive for the assumption that favism is an inherited condition and that the responsible gene is a recessive one. The penetrance of the gene seems to be high and the expression stronger in males.

\section{Antimalarials in Rheumatoid Arthritis}

During the last few years a number of authors have described the use of antimalarials in the treatment of rheumatic disorders ${ }^{1}$.

I Lancet 1957/I, 414. - J. Escarpentier-Oriol, A. CarrikasBayés, and M. SARIols-Gomez, Medizinische 1955, 1083. - J. 1"oRestier and A. Certonciny, Rev. Rhum. 21,395 (1954). - A. Frent MAN, Ann. Rhcum. Dis. 15, 251 (1956). - A. FreEdMan and I'. BACH, Lancet 1952/II, 321. - Ch. Grupper, Bull. Soc, franç. Derm. 5, 42: (1954). - G. G. HAYdu, Amer. J. med. Sci. 225, 71 (1953). - W. Hur. and L. PARR, VIIIe Congrès International du Rhumatisme, Genève 1953. - J. Lacapère, H. Monier, and G. Vial, Rev. Rhum. 21 , 389 (1954). - X. Vilanova, Klin. Wschr. 32,905 (1954).
Recent pharmacological investigations on animals throw some light upon these clinical results. We described previously ${ }^{2}$ experiments in which mepacrine, proguanil and primaquine were examined in regard to their action on the formaline-arthritis of rats; the results obtained indicated that these antimalarials possess an intensive unspecific antiinflammatory action. We believe that this quality is in question when rhoumatic disorders, lupus erythematosus, etc., are treated with antimalarials. Our earlier animal experiments were carried out under anesthesia $(100 \mathrm{mg} / \mathrm{kg}$ subcutaneously of Numal 'Roche'). We have now investigated the effects of mepacrine and chloroquine on manesthetized animals. For each substance 10 or 20 animals were used. Mepacrine or chloroquine were given by mouth, and, exactly 30 min later, inflammation was induced by the subcutaneons injection of $0.1 \mathrm{~m}$ of $3 \%$ formalin into a hind paw. Exactly $135 \mathrm{~min}$ after the injection, the animals were killed; the paw and its uninflamed fellow were immediately amputated and their volumes determined. The difference of these volumes gave the volume of swelling caused by the irritant. The antiinflammatory efficacy of the antimalarials tested was estimated by comparison of the volume of swelling in these animals with that similarly produced in control animals which had not received any anti-inflammatory treatment.

The results are summarized in the rable. They indicate, that the unspecific inhibition of inflammation by antimalarials as well in unanesthetized as in anesthetized animals corresponds to the anti-inflammatory intensity of cortisone under the same conditions.

\section{R, I)ominjo\% and W. THI:OBAL.1)}

Pharmacological Laboratories, J. R. Cicigy, Basle, Septomber 16, 1957.

\section{Zusammenfassung}

Mit Malariamitteln konnte am liormalinöslem der Ratte in einer Dosis von $50 \mathrm{mg} / \mathrm{kg}$ per os sowohl bei narkotisierten als auch bei nichtnarkotisierten Tieren eine unspexifische entzündungrshemmencle fomponente nachgewiesen werden. Die Intensität der inhibitorischen Wirkung entsprach dibei der lintzinulungshemmung von $2 \times 50 \mathrm{mg} / \mathrm{kg}$ Cortison. Unserer Ansicht nach dïrfte dieser unspezifische antiphlogistische liffekt bei der I3ehandlung rheumatischer $\Lambda$ ffektionen, des lupus erythematodes usw, mit Malariamitteln zur Cieltung kommen.

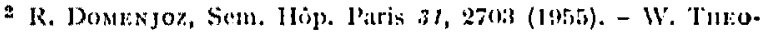

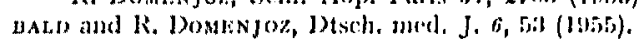

'Formaline sedema' of rats

\begin{tabular}{|c|c|c|c|c|c|c|c|}
\hline \multirow{2}{*}{ Substances } & \multicolumn{4}{|c|}{ Under anesthesia } & \multicolumn{3}{|c|}{ Without ancesthesial } \\
\hline & Cortisone & Mepacrine & Chlorwanid & P'rimacquine & Cortisone & Mepacrine & Chorrequine \\
\hline Doses in $\mathrm{mg} / \mathrm{kg}$ orally. . . . & & 50 & 50 & 50 & & 50) & 50 \\
\hline Subcutaneously.$\cdots$. & $2 \times 50$ & & & & $2 \times 50$ & & \\
\hline Number of animals... & 20 & 20 & 20 & 20 & 20 & 10 & 20 \\
\hline Volume of swelling in $\mathrm{mm}^{3}$ & 124 & 115 & 116 & 123 & 191 & 216 & 211 \\
\hline$a \pm \ldots \ldots$ & 78.28 & 48.69 & 47.88 & 55.40 & 81.68 & 68.05 & 61.94 \\
\hline$\varepsilon \pm \ldots . . . \ldots$ & $17 \cdot 50$ & $10 \cdot 89$ & $10 \cdot 71$ & $12 \cdot 38$ & $18 \cdot 20$ & $21 \cdot 81$ & 13.85 \\
\hline Significant Difference. . : . & $6 \cdot 32$ & 8.44 & 8.44 & 7.60 & $3 \cdot 65$ & 0.1 & $4 \cdot 63$ \\
\hline $\begin{array}{l}\text { Inhibition in } \% \text { in compari- } \\
\text { son to untreated controls }\end{array}$ & 54 & 57 & 57 & 54 & 33 & 38 & 37 \\
\hline
\end{tabular}

